\title{
Terminal ileal lymphoma resembling abdominal abscess
}

\author{
Ali Kemal Sivrioglu, Serkan Aribal, Hakan Onder
}

Department of Radiology, Okmeydanı Education and Research Hospital, Istanbul, Turkey

Correspondence to Dr Hakan Onder, drhakanonder@hotmail.com

Accepted 12 April 2017
CrossMark

\section{To cite: Sivrioglu AK,}

Aribal S, Onder H. BMJ Case Rep Published Online First: [please include Day Month Year]. doi:10.1136/bcr-2017220292

\section{DESCRIPTION}

A 23-year-old man presented to the emergency service with abdominal pain. The ultrasound study showed an area with thick wall and internal air-fluid levels. Appendix vermiformis could not be distinguished as a dividual structure. Radiological appearance was thought to be periapendicular abscess due to the perforation of appendix vermiformis. However, due to the persistence with normal small bowel loops shown, this area could be a possible dilated bowel loop with mural thickening. Therefore, contrast-enhanced abdominal CT examination was performed. CT showed aneurysmal dilatation and minimally enhancing mural thickening which reaches $3 \mathrm{~cm}$ in one wall, from right lower quadrant to left lower quadrant in an approximately $20 \mathrm{~cm}$ terminal ileal segment. This segment included ileocaecal valve (figure 1A, B). In retrocaecal region, appendix vermiformis diameter was in normal limits $(6 \mathrm{~mm})$, but there was no inflammatory finding in the fatty planes (figure 1C). Findings were well-matched primary gastrointestinal lymphoma. The diagnosis was corrected with positron emission tomography and laparotomy.

Lymphomas are nearly half of all primary intestinal tumours. The most common place for extranodal non-Hodgkin lymphomas is the gastrointestinal system. The stomach is the most involved organ in the gastrointestinal system. ${ }^{1}$ There are three types which show different views radiologically, namely, circumferential type, polypoid form and mesenteric

\section{Learning points}

- The most common place for extranodal non-Hodgkin lymphomas is gastrointestinal system. The stomach is the most involved organ.

- Circumferential-type non-Hodgkin lymphomas are especially seen with aneurysmal dilatation and mural thickening.

- It should be kept in mind that terminal ileal lymphoma may resemble abdominal abscess.

forms. Within these types, circumferential type is especially seen with aneurysmal dilatation and mural thickening. It should be kept in mind that terminal ileal lymphoma may resemble abdominal abscess as in this case.

Contributors AKS, SA and HÖ conceived the paper. AKS and SA assembled the case history from hospital records. AKS and SA participated in writing of the paper. HÖ approved the final version.

Competing interests None declared.

Patient consent Obtained.

Provenance and peer review Not commissioned; externally peer reviewed.

(c) BMJ Publishing Group Ltd (unless otherwise stated in the text of the article) 2017. All rights reserved. No commercial use is permitted unless otherwise expressly granted.

\section{REFERENCE}

1 Ghimire P, Wu GY, Zhu L. Primary gastrointestinal lymphoma. World I Gastroenterol 2011;17:697-707.

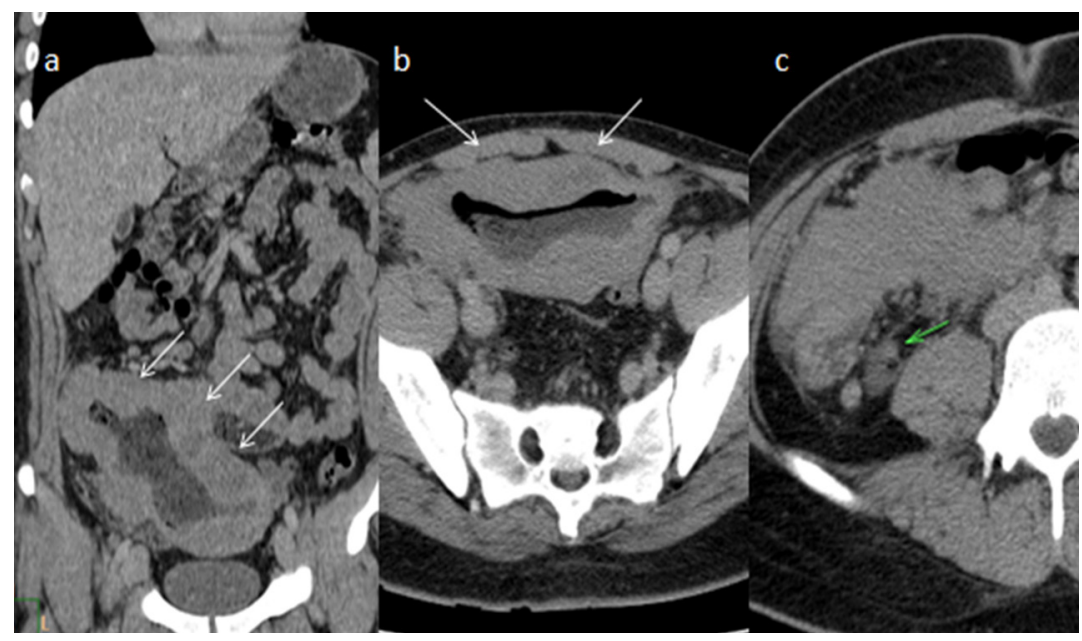

Figure 1 Contrast-enhanced abdominal CT coronal (A) and axial (B) images show aneurysmal dilatation and minimally enhancing mural thickening in terminal ileal segment. In retrocaecal region, appendix vermiformis diameter is in normal limits $(6 \mathrm{~mm})$ with minimal periappendiceal fluid (C). 
Copyright 2017 BMJ Publishing Group. All rights reserved. For permission to reuse any of this content visit http://group.bmj.com/group/rights-licensing/permissions.

BMJ Case Report Fellows may re-use this article for personal use and teaching without any further permission.

Become a Fellow of BMJ Case Reports today and you can:

- Submit as many cases as you like

- Enjoy fast sympathetic peer review and rapid publication of accepted articles

Access all the published articles

- Re-use any of the published material for personal use and teaching without further permission

For information on Institutional Fellowships contact consortiasales@bmjgroup.com

Visit casereports.bmj.com for more articles like this and to become a Fellow 